\title{
NodeMcu Microcontroller Based Disinfectant Fluid Monitoring System Using Water Level Control Sensor and Ultrasonic Sensor
}

\author{
Rama Sahtyawan ${ }^{1, *}$, Andika Bayu Saputra ${ }^{2}$, Syaeful Arief $^{3}$ \\ ${ }^{1}$ Prodi Teknologi Informasi, ${ }^{2}$ Prodi Informatika, ${ }^{3}$ Prodi Teknik Industri \\ Fakultas Teknik dan Teknologi Informasi, Universitas Jenderal Achmad Yani Yogyakarta \\ Email Korespondensi : 'ramasahtyawan@gmail.com
}

Received: 3 September 2020; Accepted : 13 Oktober 2020; Published : 1 November 2020

\begin{abstract}
ABSTRAK
Penyebaran virus corona (Covid-19) di Indonesia semakin meningkat. banyak inovasi mulai timbul diantarnya penggunaan bilik/chamber yang diletakkan dijalan, pintu gerbang kampung masih secara manual dengan adanya petugas yang menekan saklar bagi tamu yang masuk, dan ada juga penyemprotan yang dilakukan secara otomatis, membaca tamu yang datang, secara otomatis, Kendala yang dihadapi terkadang kehabisan cairan desinfektannya, menuntut petugas mesti mengecek secara rutin agar tidak kehabisan. penelitian ini akan mengembangkan bilik desinfektan berbasis IoT selain dapat menyemprotkan cairan desinfektan secara otomatis, juga dapat mengisi cairan desinfektan secara otomatis dan dapat dipantau melalui Smartphone. Kebutuhan sistem dan alatnya terdiri dari : NodeMcu Esp 8266, sensor flow water, sensor ultrasonic, Relay, Solenoid Valve, Arduino IDE, Blynk Apps, ThingSpeak Proses pendeteksian ketinggian cairan desinfektan tersebut dibedakan menjadi 2, level aman dengan ketinggian air antara 11-50 cm, Level bahaya dengan ketinggian air antara 0-10 cm, maka nodemcu mengirimkan sinyal output ke relay, relay meneruskan sinyal tersebut yang berfungsi sebagai saklar untuk membuka solenoid, air akan mengalir melalui pipa saat katup solenoid dibuka sehingga kran air terbuka untuk mengisi derigen. Platform Iot Thingspeak digunakan untuk menampilkan grafik level cairan desinfektan. Data output sensor akan dilaporkan secara real time ke admin melalui aplikasi Blynk apps. Dengan perkembangan perangkat ini, diharapkan dapat menekan penyebaran virus covid-19.
\end{abstract}

Kata kunci: NodeMcu, Pengatur Ketinggian Air, Sensor Ultrasonik.

\begin{abstract}
The spread of the coronavirus (Covid-19) in Indonesia is increasing. Many innovations have begun to emerge between the use of chambers that are placed on the streets is rampant, the village gate is still manually with an officer pressing the switch for incoming guests, and there is also spraying that is done automatically, reads guests who come, automatically, the obstacles encountered are sometimes run out of disinfectant fluid, demanding officers must regularly check so as not to run out. This research will develop an IoT-based disinfecting booth in addition to spraying disinfecting liquid automatically. It can also fill disinfecting liquid automatically and can be monitored via a Smartphone. System and tool requirements consist of NodeMcu Esp 8266, flow water sensor, ultrasonic sensor, Relay, Solenoid Valve, Arduino IDE, Blynk Apps, ThingSpeak The process of detecting disinfectant fluid level is divided into 2, safe level with water level between 11-50 cm, The danger level with the water level between $0-10 \mathrm{~cm}$. Then the node sends an output signal to the relay. The relay continues that signal, which functions as a switch to open the solenoid, water will flow through the pipe when the solenoid valve is opened so that the water tap is open to fill the derijen. The Thingspeak IoT platform is used to display disinfectant liquid level graphs. Sensor output data will be reported in real-time to the admin via the application of the Blynk app. With the development of this device, it is expected to reduce the spread of the COVID-19 virus.
\end{abstract}

Keywords: NodeMcu, Water Level Control, Ultrasonic Sensor.

\section{Pengantar}

Covid atau Coronavirus disease 2019 adalah penyakit menular yang disebabkan oleh infeksi virus SARS-CoV-2. Diagnosis Infeksi Covid-19 menyebar dari satu orang ke orang lain melalui percikan (droplet) dari saluran pernapasan yang sering dihasilkan saat batuk atau bersin [1]. Menurut Detik.com kamis(30/4/2020) terdapat sebanyak 347 kasus baru positif sehingga untuk total sekarang ada 10.118 kasus, ada sebanyak 1.522 sembuh dan 792 meninggal dunia. Meskipun belum ada pengobatan yang efektif untuk mencegah penyakit ini, akan tetapi penyebarannya bisa ditekan salah satunya menggunakan menyemprotkan desinfektan. Di Vietnam cairan desinfektan digunakan dirumah, bilik perkantoran, cara tersebut cukup efektif karena angka kematian relatif kecil [2]. Menurut WHO keberadaan bilik harus diperhatikan cairan desinfektannya tidak menggunakan alkohol dan bahan kimia berlebihan karena dapat berbahaya jika terkena selaput lender, muka dan mata. Di Korea penggunaan bilik desinfektan, seseorang yang masuk. bilik tersebut menggunakan masker dengan mata dipejamkan dan tangan yang menutup telinga [3]. Di Indonesia mulai marak penggunaan bilik/chamber yang diletakkan dijalan, pintu gerbang kampung, sejumlah instansi pemerintahan untuk tamu yang datang harus melalui bilik desinfektan tersebut untuk memastikan tamu tersebut steril tidak membawa bibit covid19.

Terdapat beberapa permasalahan yang dihadapi bilik desinfektan tersebut cara kerja penyemprotannya masih dilakukan secara manual dengan adanya petugas yang menekan saklar bagi tamu yang masuk dianggap 
masih kurang efektif menuntut petugas harus standby mengecek keluar masuk tamu, adapula yang sudah menerapkan sensor, akan tetapi belum terhubung internet, terkadang kehabisan cairan desinfektannya menuntut petugas mesti mengecek secara rutin agar tidak kehabisan.

Solusi yang dilakukan adalah penerapan sebuah bilik desinfektan berbasis IoT selain dapat menyemprotkan cairan desinfektan secara otomatis, juga dapat memonitoring cairan desinfektan secara otomatis dapat dipantau melalui Smartphone agar tidak kehabisan cairan tersebut. Perangkat ini akan memanfaatkan sensor sensor flow water, sensor ultrasonic, Relay, Solenoid Valve. Data keluaran sensor tersebut akan secara real-time dimonitoring pengguna melalui aplikasi Blynk dan bisa dilihat untuk tampilan grafiknya melalui thingspeak yang dapat dilihat melalui handphone, memudahkan admin kampus dalam memonitoring cairan desinfektan tersebut.

\section{Metodologi Penelitian}

Penelitian ini bermula dengan melakukan telaah pada permasalahan dengan melihat relevansinya untuk mencari penciri khas pembeda pada penelitian-penelitian sebelumnya, Penelitian ini dilakukan menggunakan diagram fishbone dijelaskan pada gambar 1 dibawah ini :

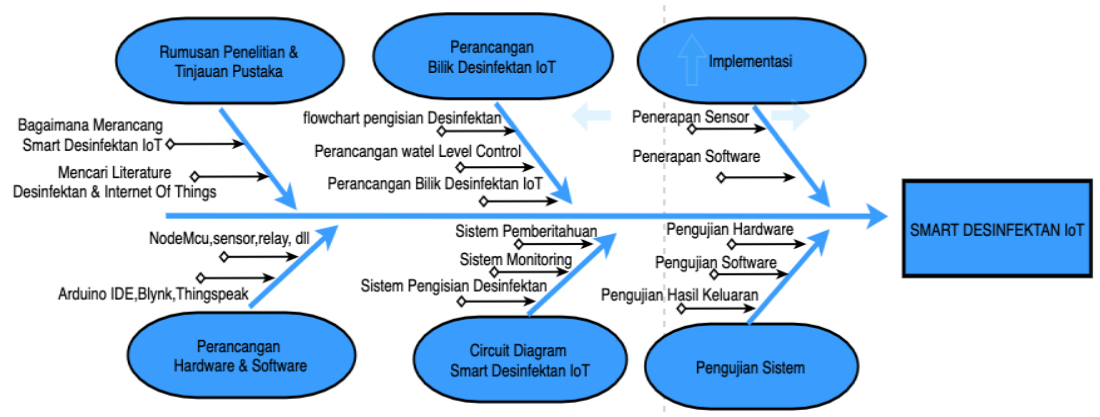

Gambar1. Roadmap penelitian

Pada perumusan penelitian ini bermula dengan melakukan telaah pada permasalahan dengan melihat relevansinya untuk mencari penciri khas pembeda pada penelitian-penelitian sebelumnya, seperti pada penelitian penerapan sensor-sensor diantaranya : pengontrolan aliran air menggunakan sensor pengontrol dengan menerima input volume air [4]. Pemantau daerah endemik malaria berbasis IoT [5]. Sistem irigasi pompa dan alat penyiram berbasis Arduino menggunakan sensor water flow [6]. Penerapan water level control untuk mendeteksi tingkat air dalam tangki secara otomatis menggunakan arduino [7] dan juga Aplikasi untuk Kontrol Lampu Jarak Menggunakan Mikrokontroler Nodemcu Esp 8266 Berbasis Internet of Things (IoT) [8] dan juga dibutuhkan keamanan computer untuk melindungi dari serangan hacker [9] sehingga penerapan sensor bisa berjalan baik tanpa adanya hambatan transmisi datanya.

Pembaharuan orisinil dari penelitian ini adalah sebagai pembaharuan dari bilik desinfektan yang sudah ada yaitu bilik tersebut sudah menerapkan adanya beberapa sensor, akan tetapi masih bersifat stand alone atau sistem tersebut masih bersifat mandiri dan belum terhubung dengan internet. Untuk penelitian ini dirancang bilik desinfektan yang terintegrasi dengan beberapa sensor yang terhubung dengan internet, sistem tersebut dapat dimonitoring level cairan derijen tersebut melalui handphone, sehingga meminimalisir adanya kehabisan cairan diderijen tersebut.

\subsection{Perancangan Hardware dan Software.}

Analisis kebutuhan menjelaskan susunan secara keseluruhan terkait dengan hardware / perangkat keras yang mengintegrasikan sistem dengan platform IoT yaitu terdiri: NodeMcu Esp 8266 ialah firmware interaktif berbasis LUA memiliki 4MB flash, 11 pin GPIO dimana 10 diantaranya dapat digunakan untuk PWM, 1 pin ADC, 2 pasang UART, WiFi 2,4GHz serta mendukung WPA/ WPA2, diprogram dengan Bahasa C dan support terhadap Arduino IDE. Water Level Control adalah alat yang mengidentifikasi ketinggian air pada bak penampungan, yang mana alat ini berfungsi untuk mengontrol kerja motor pompa air untuk mengisi bak penampungan air [10]. Relay adalah switch elektrik yang dioperasikan secara listrik dan terdiri dari 2 bagian utama yaitu elektromagnet dan seperangkat kontak saklar/switch sehingga dengen arus listrik yang kecil dapat menghantarkan listrik dengan tegangan yang lebih tinggi yang dapat mengefisienkan energi dan kehandalan koneksi [11]. Solenoid valve adalah katup yang dikendalikan secara elektrik berdasarkan besarnya arus, mempunyai kumparan sebagai penggeraknya yang berfungsi untuk menggerakan piston yang dapat digerakan oleh arus AC maupun DC [12]. Sensor ultrasonik ialah dengan mendeteksi jarak suatu objek dengan memancarkan gelombang ultrasonik $(40 \mathrm{khz})$ selama $\mathrm{t}_{\text {BURST }}(200 \mu \mathrm{s})$ kemudian mendeteksi pantulannya.

Analisis software yang digunakan dalam penelitian ini menggunakan : Arduino IDE adalah sketch yang dibuat menggunakan bahasa pemrograman C. dan bisa langsung dicompile dan diupload yang diprogram 
kedalam microcontroller. Blynk Apps adalah Platform yang digunakan dalam aplikasi OS Mobile (iOS dan Android) yang bertujuan untuk kendali microcontroler. Membantu dalam segala bisnis yang terhubung ke Internet of Things diantarnya untuk mengurus pembangunan aplikasi seluler, layanan cloud. ThingSpeak adalah platform open source Internet of Things (IOT) aplikasi dan API untuk menyimpan dan mengambil data dari hal menggunakan protokol HTTP melalui Internet atau melalui Local Area Network. platform ini menggunakan pengontrol mikro Arduino serta komunikasi dengan sistem operasi antarmuka grafis melalui skrip Python [13]. Cara kerja modul sensor ultrasonik ialah dengan mendeteksi jarak suatu objek dengan memancarkan gelombang ultrasonik $(40 \mathrm{khz})$ selama $\mathrm{t}_{\mathrm{BURST}}(200 \mu \mathrm{s})$ kemudian mendeteksi pantulannya [14].

\subsection{Flowchart Pengisian Desinfektan}

Flowchart atau Bagan alir digunakan untuk menunjukan flow didalam program atau prosedur sistem secara logika pengisian desinfektan, adapun tampilan flowchartnya sebagai berikut :

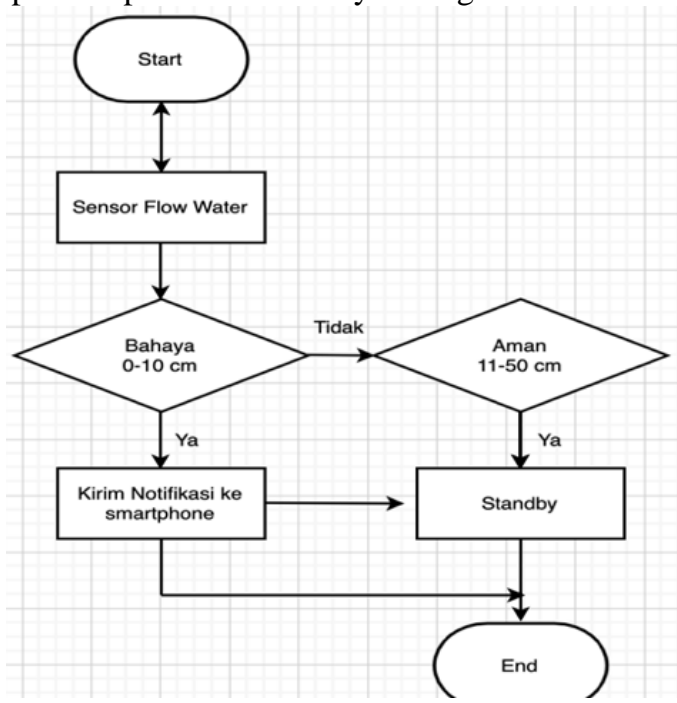

Gambar 2 Flowchart pengisian desinfektan

Penjelasan gambar 2 pengisian desinfektan digunakan sebagai acuan untuk mengontrol kondisi cairan ada dirijen utama, pada water level control diberikan dua rule: bahaya dan aman. Bahaya apabila ketinggian cairan 0-10 cm, aman apabila ketinggian $11-50 \mathrm{~cm}$, indikator aman dan bahaya nantinya akan dirancang pada sistem yang akan tertampil pada blynk app.

\subsection{Perancangan Water Level Control}

Pada Water Level Control bekerja dengan menggunakan tiga sensor, yaitu sensor 3 yang berfungsi sebagai pemicu tegangan yang nantinya disalurkan ke sensor 2 dan sensor 1 untuk menghantarkan tegangan sebagai pengendali Transistor $1(Q 1)$, sedangkan sensor 2 digunakan sebagai pengendali Transistor $2(Q 2)$ dan Sensor 3 berfungsi dalam menghantarkan tegangan sebagai pengendali SCR yang nantinya berguna untuk mengatur kerja dari rangkaian water level control (WLC).

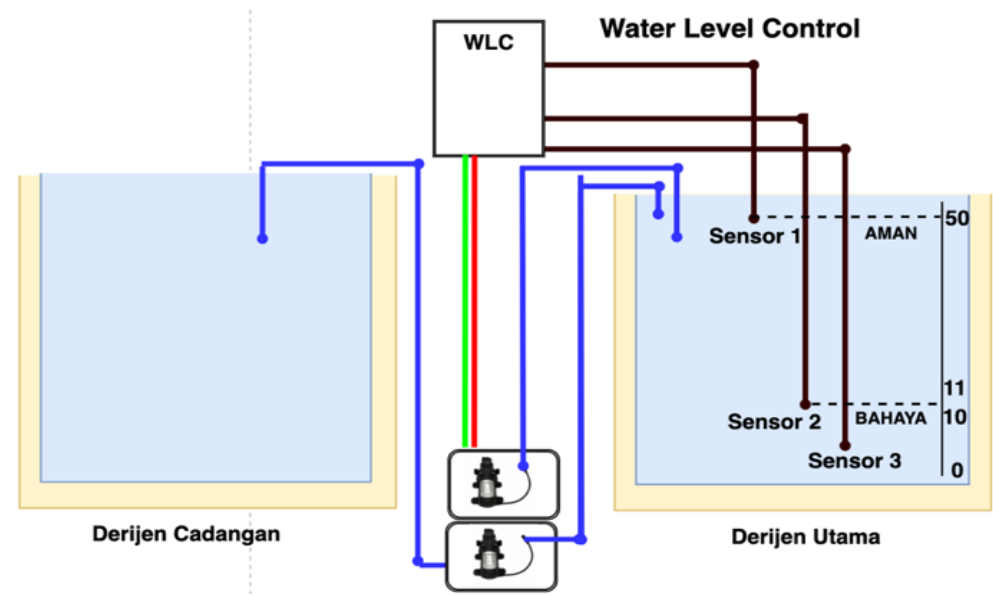

Gambar 3 prinsip kerja water level control 
Penjelasan Gambar 3 prinsip kerja water level control sebagai berikut : Pada saat sensor 3 terkena air maka Transistor Q1 Aktif (on), Transistor Q2 Tidak aktif (off) dan keadaan SCR tidak aktif (off), solenoid valve menyala. Setelah sensor 2 terkena air maka Transistor Q1 Aktif (on) dan Transistor $Q 2$ hampir on, solenoid valve menyala pada level bahaya antara $(0-10 \mathrm{~cm})$. Saat air mencapai sensor 1 maka $S C R$ on dan Transistor $Q 2$ Aktif (on) dan Transistor Q1 Tidak Aktif (off). Pada saat kondisi ini solenoid valve akan mati karena transistor Q1 tidak aktif (off) yang menyebabkan relay tidak aktif (off), maka saklar No relay akan memutus, dan ini pada level aman antara $11-50 \mathrm{~cm}$, Saat air mulai habis dan turun hingga Sensor 2 tidak terkena air lagi maka solenoid valve akan menyala kembali.

\subsection{Perancangan Bilik Desinfektan IoT}

Pada perancangan bilik desinfektan IoT digunakan untuk acuan dalam pelaksanaan pembuatan bilik, adapun tampilan gambarnya sebagai berikut :

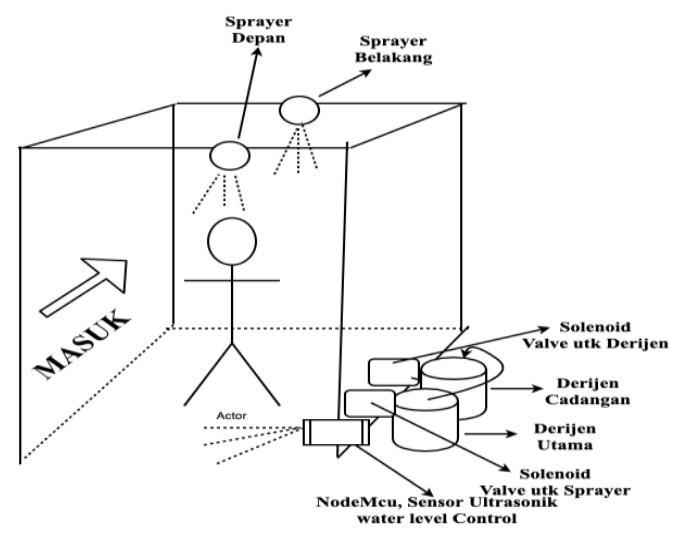

Gambar 4 perancangan bilik desinfektan IoT

Penjelasan gambar 4 pada bilik dirancang nantinya berbentuk kotak menggunakan besi agar lebih kuat, pada pintu masuk terdapat box yeng terdiri NodeMcu, water level control,sensor ultrasonik untuk mendeteksi objek pengguna, sehingga sistem dapat membaca sinyal untuk meneruskan dan menyemprotkan sprayer yang terdapat didepan dan belakang. Tools hardware pendukung lainnya terdapat 2 solenoid yang berfungsi untuk sprayer dan untuk derijen. Terdapat 2 derijen, yaitu derijen utama yang digunakan sebagai penampung cairan dan juga terdapat derijen cadangan untuk mensuplay cairan ke derijen utama apabila sudah mencapai batas bahaya.

\subsection{Circuit Diagram.}

Pada Circuit digram berisi perancangan desain sistem pengisian cairan desinfektan otomatis terdiri dari tiga fungsi utama yaitu sistem pengisian desinfektan, sistem monitoring, dan sistem pemberitahuan. Adapun gambarnya sebagai berikut :

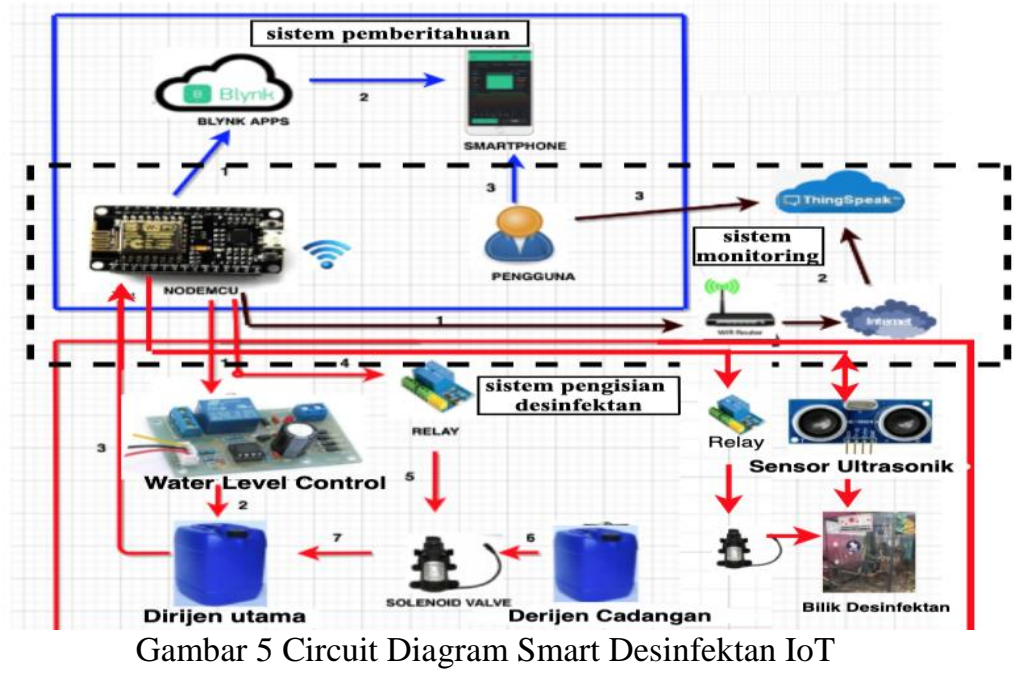


Penjelasan gambar 5 Sistem pemberitahuan pengisian desinfektan, sistem mengirimkan pemberitahuan ke smartphone pengguna, pada saat sistem pengisian desinfektan diaktifkan, pengguna mendapat pemberitahuan di smartphone. Ketika perangkat penyiraman telah dinonaktifkan, pengguna mendapat pemberitahuan bahwa perangkat dinonaktifkan. Diolah dijelaskan sebagai berikut: Sistem penyiraman yang telah aktif atau dinonaktifkan kemudian akan mengirim data ke Blynk Apps. Aplikasi Blynk mendapatkan data dari mikrokontroler NodeMcu, memproses data, dan mengirim pemberitahuan ke smartphone pengguna. Pengguna dapat memeriksa pemberitahuan di Blynk Apps di smartphone tentang sistem pengisian desinfektan apakah diaktifkan atau dinonaktifkan.

Sistem monitoring pengisian desinfektan menggunakan Thingspeak dengan tahapan: sinyal yang diproses flow water untuk mendeteksi cairan berhasil diterima oleh nodeMcu yang terhubung akses wi-fi mengirimkan data cloud ke thingspeak. Pengguna dapat dengan mudah memonitoring dengan mengakses situs thingspeak dengan menggunakan browser dari smartphone atau komputer dengan mengakses situs thingspeak melalui bentuk grafik.

Sistem pengisian desinfektan: Water Level Control (WLC) terhubung nodemcu untuk mendeteksi level ketinggian cairan desinfektan yang ada didalam derigen, WLC mengirimkan sinyal analog diproses dalam mikrokontroler nodemcu, nodemcu mengirimkan sinyal output ke relay, relay meneruskan sinyal tersebut yang berfungsi sebagai saklar untuk membuka atau menutup solenoid sesuai dengan input yang diberikan, katup solenoid membuka katup saat relay aktif dan menutup katup jikalau relay mati.

\section{Hasil Dan Pembahasan}

Objek yang akan dilakukan didalam pengujian ini menggunakan bilik desinfektan dalam upaya menekan penyebaran covid-19, adapun tampilannya sebagai berikut :

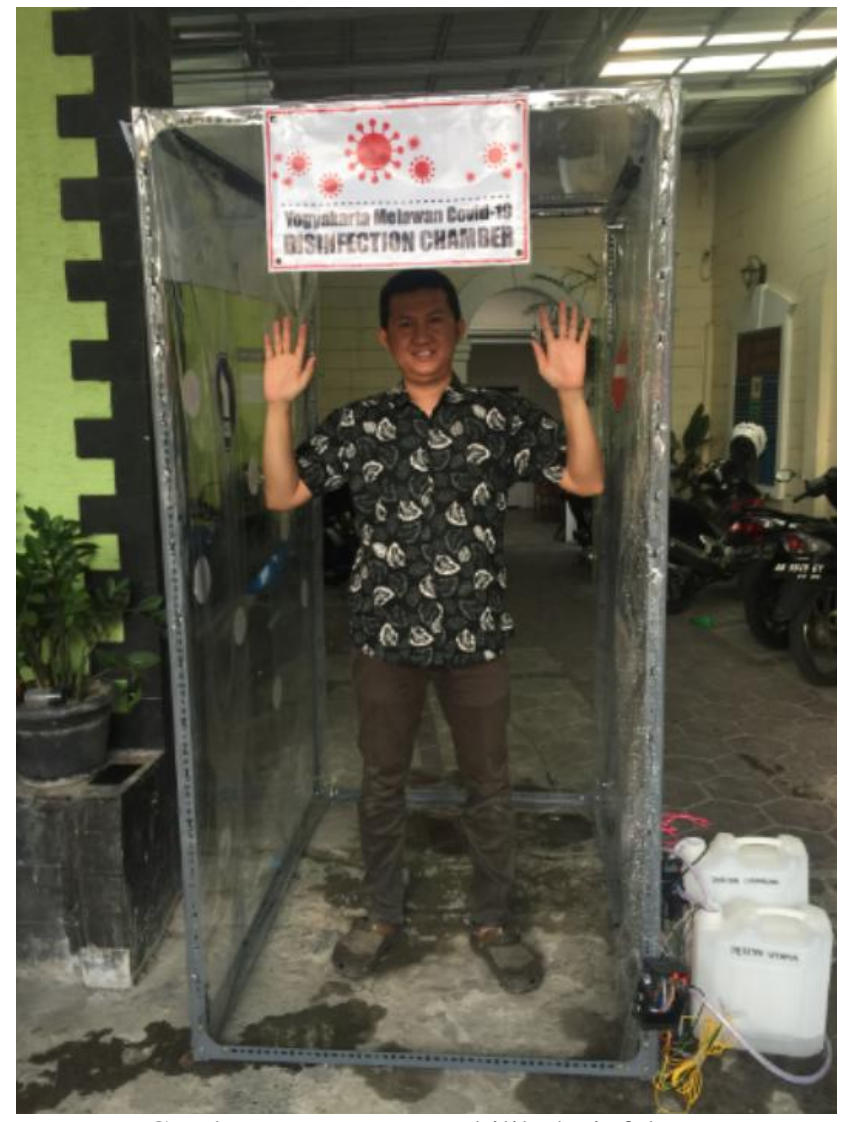

Gambar 6.a purwarupa bilik desinfektan 


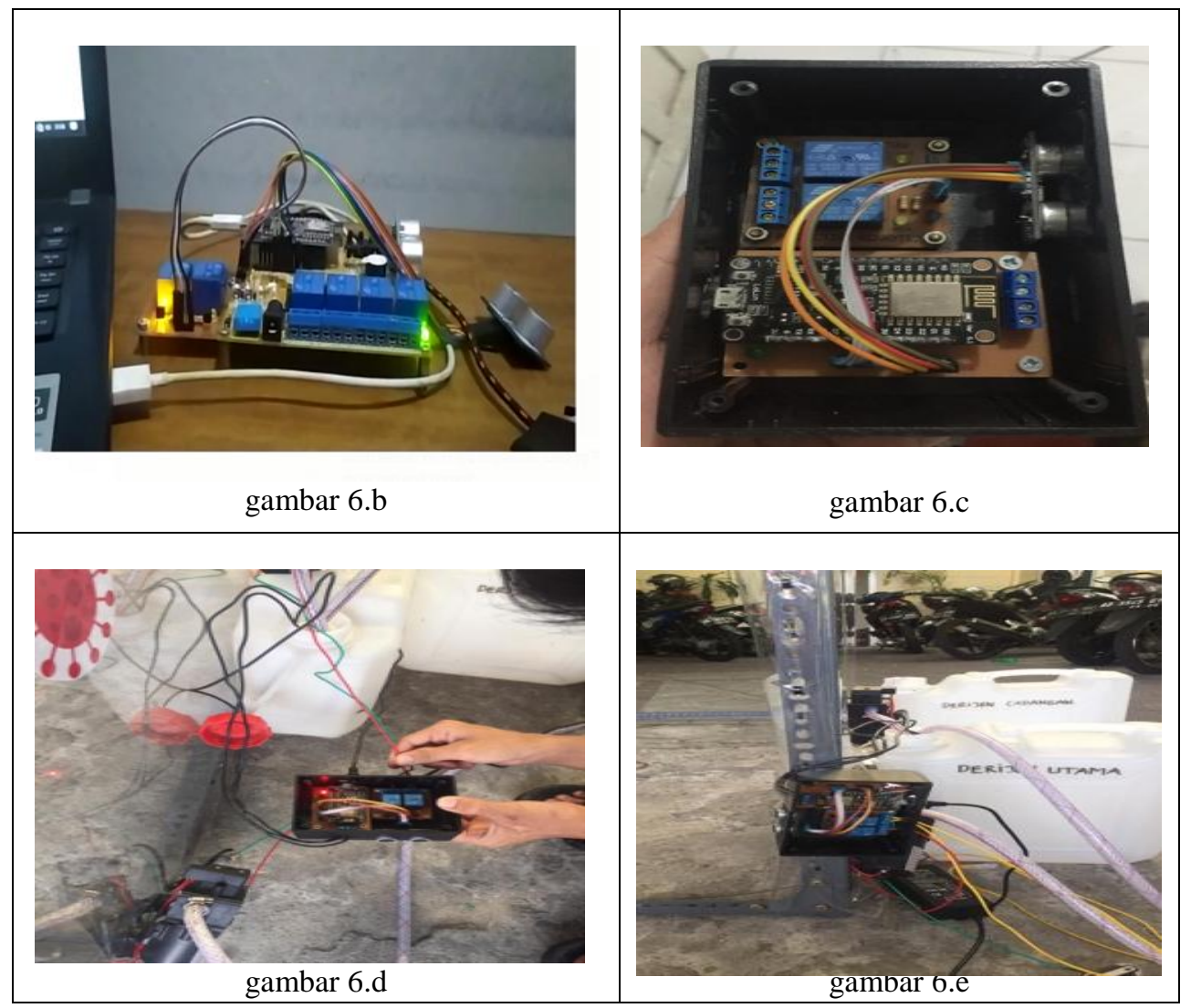

Penjelasan gambar 6a purwarupa bilik desinfektan diatas, pada tahap awal melakukan perakitan sensor dan melakukan pengetesan langsung dilaptop untuk melihat perkembangan alat apakah sudah dapat di run dan berjalan baik tertampil pada gambar 6b, langkah selanjutnya membuat box pada gambar 6c untuk mengumpulkan tools yang terdiri NodeMcu, water level control, sensor ultrasonik agar lebih mudah diintegrasikan dan diaplikasi pada saat pemasangan bilik desinfektan, langkah selanjutnya melakukan pengetesan box pada gambar $6 \mathrm{~d}$ untuk mengkolaborasikan dengan tools lainnya seperti derijen, solenoid, tahap selanjutnya memasang box sensor didepan pintu masuk bilik seperti pada gambar 6e agar dapat mendeteksi apabila ada tamu yang memasuki bilik tersebut dan selanjutnya mengirimkan sinyal tersebut ke relay, maka relay akan menangkapnya untuk menghidupkan sprayer untuk menyemprotkan tamu tersebut

\subsection{Implementasi Sistem}

Implementasi sistem menggunakan aplikasi Blynk yang ditunjukkan pada gambar 7. Terdapat dua jenis pemberitahuan keadaan cairan pada level bahaya dan aman yang dapat dilihat pada smartphone pengguna, adapun tampilannya sebagai berikut :

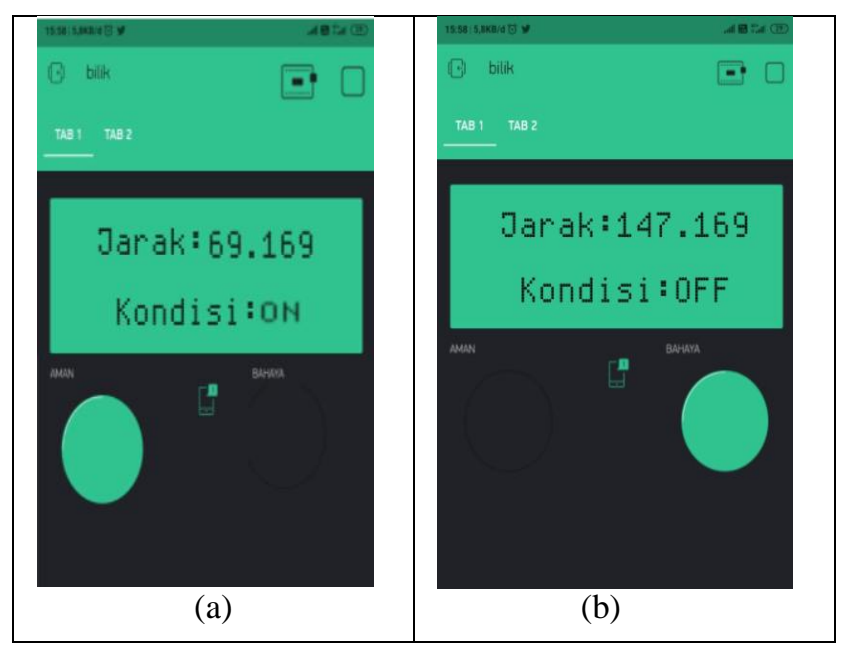

Gambar 7 Tampilan Blynk di HP 
Penjelasan pada gambar 7 aplikasi blynk menampilkan kondisi level cairan bilik desinfektan pada posisi ON, pada Level = aman yang ditunjukkan pada gambar 7a, dan ada info tambahan dengan tertera jarak terakhir sensor dengan tamu yang memasuki bilik. pada gambar $7 \mathrm{~b}$ menampilkan kondisi bilik desinfektan pada posisi ON, pada Level cairan = bahaya. Pada Tampilan Blynk diatas memerlukan pengkodean program dengan menggunakan konfigurasi Arduino IDE, adapun tampilannya sebagai berikut

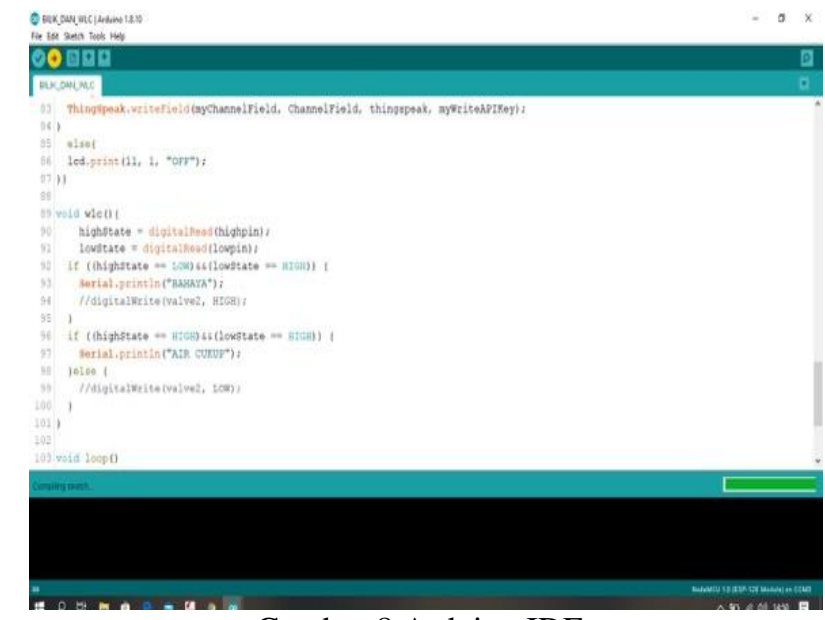

Gambar 8 Arduino IDE

Penjelasan gambar 8, Arduino IDE digunakan untuk menulis dan mengunggah kode cairan desinfektan dalam keadaan aman maupun bahaya ke dalam instrument arduino, sehingga inputan sinyalnya dapat dibaca oleh nodemcu dan sensor sehingga menghasilkan output yang dapat ditampilkan melalui blynk. Untuk tampilan thingspeaknya sebagai berikut :

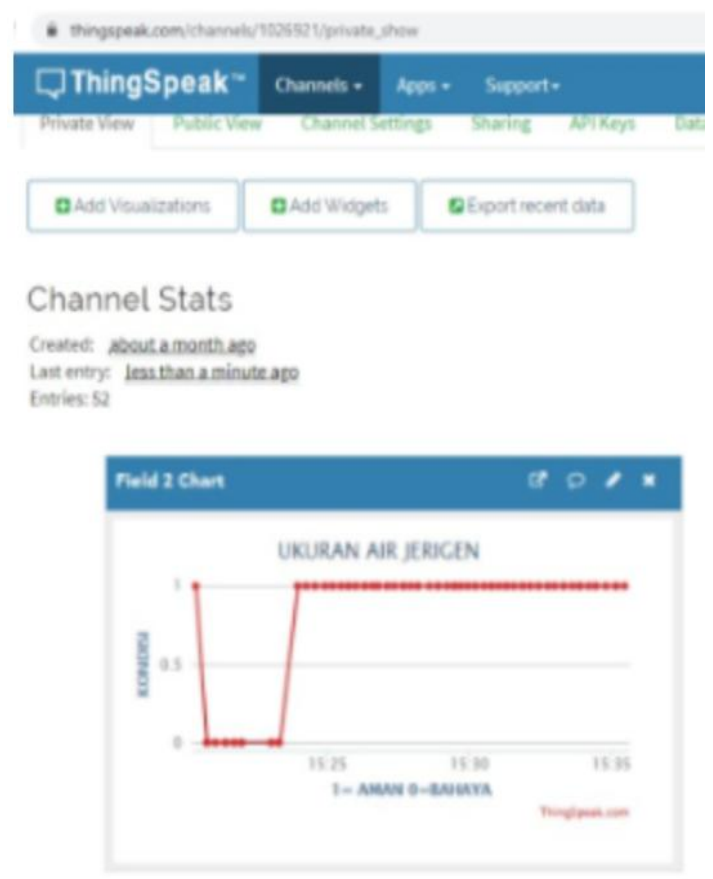

Gambar 9 Tampilan ThingSpeak

Penjelasan gambar 9 merupakan tampilan pada Thingspeak yang menampilkan ukuran air jerigen dengan menggunakan dua indikator level aman dan bahaya digunakan untuk memberikan informasi mengenai indicator level air pada waktu dijalankan sesuai dengan kondisi realnya.

\subsection{Pengujian Sistem.}

Pengujian dilakukan untuk mengetahui apakah sistem pengisian desinfektan dapat bekerja dengan baik atau tidak. Pengujian dilakukan menggunakan metode pengujian kotak hitam. Tes dilakukan dalam tiga bagian. 
Bagian pertama adalah pengujian perangkat untuk menguji fungsionalitas perangkat keras. Pengujian kedua terkait dengan pemantauan water level control pada aplikasi Blynk. Pengujian bagian ketiga adalah tentang pemberitahuan melalui aplikasi Thingspeak.

\section{a) Pengujian Fungsi Perangkat keras pada pemantau stok cairan}

Pengujian fungsi perangkat keras dilakukan untuk mengetahui fungsi water level control, nodemcu, relay, solenoid, pipa air dapat berfungsi dengan baik untuk mendukung sistem pemantauan stok cairan desinfektan, pengujian dilakukan dengan menguji perangkat keras dan water level control dalam mengukur ketinggian air di dalam wadah setinggi $50 \mathrm{~cm}$ yang akan tampil pada blynk. Adapun tampilan dapat dilihat pada Tabel 1.

Tabel 1. Pengujian Fungsi Perangkat Keras

\begin{tabular}{ccccc}
\hline $\begin{array}{c}\text { Ketinggian } \\
\text { derigen }\end{array}$ & NodeMcu & Relay & $\begin{array}{c}\text { solenoid } \\
\text { valve }\end{array}$ & hasil tes \\
\hline $11-50$ & on & off & close & sukses \\
$0-10$ & on & on & open & sukses \\
\hline
\end{tabular}

\section{b) Pengujian Sensor Flow water pada Blynk}

Pengujian dilakukan untuk mengetahui apakah sensor ketinggian air dalam hal ini menggunakan water level control bekerja dengan baik. Pengujian di lakukan 10x percobaan dalam hari yang berbeda. water level control dapat membaca kondisi sesuai dengan keadaan air dalam tendon apakah aman / berbahaya, dengan membutuhkan waktu pengiriman data, tetapi ada 1 data yang tidak terkirim dimana ada kegagalan pengiriman data bisa terjadi ketika provider mengalami gangguan. Untuk tampilan pada aplikasi sudah sesuai dengan kondisi data yang di kirim dari sensor. Proses monitoring secara real time berhasil dilakukan sehingga kaidah dari IoT tercapai. Adapun tampilan dapat dilihat pada Tabel 2.

Tabel 2. Pengujian Water Level Control

\begin{tabular}{cccc}
\hline Exp & Ketinggian derigen & $\begin{array}{c}\text { Waktu } \\
\text { (detik) }\end{array}$ & TampilanBlynk \\
\hline 1 & 50 & 4 & aman \\
2 & 43 & 5 & aman \\
3 & 35 & 3 & aman \\
4 & 20 & 4 & aman \\
5 & 15 & gagal & tidak tampil \\
6 & 10 & 4 & bahaya \\
7 & 50 & 5 & aman \\
8 & 35 & 3 & aman \\
9 & 24 & 4 & aman \\
10 & 8 & 5 & bahaya \\
\hline
\end{tabular}

c)

\section{Pengujian water level control pada Thingspeak}

Pengujian fungsi perangkat keras dilakukan untuk mengetahui fungsi water level control, dapat berfungsi dengan baik untuk mendukung laporan melalui Thingspeak, pengujian dilakukan dengan menguji water level control dalam mengukur ketinggian air di dalam wadah setinggi $50 \mathrm{~cm}$ dengan variasi jarak $5 \mathrm{~cm}$ yang akan tampil pada Thingspeak melalui proses pengiriman data ke server. Adapun tampilan tabelnya sebagai berikut: :

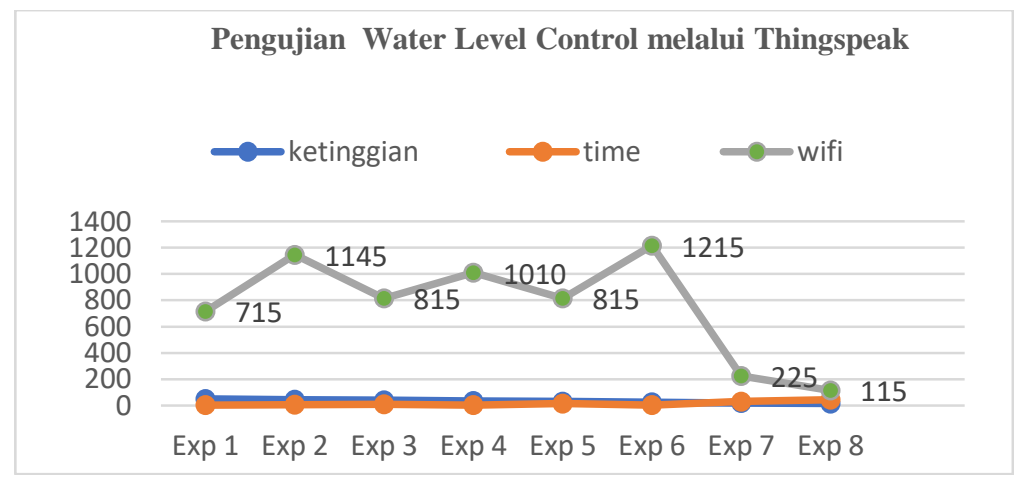

Gambar 10 Pengujian Water Level Control 


\section{d) Evaluasi Kualitas sistem.}

Setelah melakukan pengujian terhadap fungsi perangkat keras, maka peneliti melakukan evaluasi terhadap kuliatas sistem untuk mengetahui ketahanan uji dari nodemcu, relay, solenoid tersebut, sehingga nantinya diketahui jumlah sukses dan eror yang dihasilkan dapat dilihat pada Tabel 3.

Tabel 3. Ketahanan uji dari nodemcu, relay, solenoid

\begin{tabular}{|c|c|c|c|c|}
\hline Exp & NodeMcu & Relay & $\begin{array}{r}\text { solenoid } \\
\text { valve } \\
\end{array}$ & hasil tes \\
\hline 1 & on & on & open & sukses \\
\hline 2 & on & on & open & sukses \\
\hline 3 & off & off & close & gagal \\
\hline 4 & on & on & open & sukses \\
\hline 5 & on & on & open & sukses \\
\hline 6 & on & on & open & sukses \\
\hline 7 & off & off & close & gagal \\
\hline 8 & on & on & open & sukses \\
\hline 9 & on & on & open & sukses \\
\hline 10 & off & off & close & gagal \\
\hline
\end{tabular}

\section{Kesimpulan.}

Berdasarkan pengujian dan analisa yang telah dilakukan, maka didapatkan kesimpulan :

a. Sistem pengisian desinfektan menggunakan water level control telah berhasil dilakukan dengan dapat mendeteksi level cairan aman dan bahaya.

b. Nodemcu dapat menerima masukan water level control, relay dapat mematikan dan menghidupkan solenoid valve secara otomatis sesuai level cairan desinfektan

\section{Daftar Pustaka}

[1] C. C. Lai, T. P. Shih, W. C. Ko, H. J. Tang, dan P. R. Hsueh, "Severe acute respiratory syndrome coronavirus 2 (SARS-CoV-2) and coronavirus disease-2019 (COVID-19): The epidemic and the challenges," International Journal of Antimicrobial Agents, vol. 55, no. 3. Elsevier B.V., hal. 105924, 01-Mar-2020, doi: 10.1016/j.ijantimicag.2020.105924.

[2] H. T. Le et al., "The first infant case of COVID-19 acquired from a secondary transmission in Vietnam," Lancet Child Adolesc. Heal., 2020, doi: 10.1016/s2352-4642(20)30091-2.

[3] H. M. Kim, I. S. Shim, Y. W. Baek, H. J. Han, P. J. Kim, dan K. Choi, "Investigation of disinfectants for foot-and-mouth disease in the Republic of Korea," Journal of Infection and Public Health. 2013, doi: 10.1016/j.jiph.2013.04.002.

[4] M. Suresh, U. Muthukumar, dan J. Chandapillai, "A novel smart water-meter based on IoT for city distribution management," in TENSYMP 2017 - IEEE International Symposium on T. for SmartCities,2017,doi:10.1109/TENCONSpring.2017.8070088.

[5] R. Sahtyawan dan Sudarmana landung, "Rancang Bangun Pemantau Daerah Endemik Malaria Berbasis IoT Menggunakan Metode Profile Matching," Piltek vol. 5, no. 1, Maret 2020,doi: 10.33319/piltek.2020.v5i1.51.

[6] S. Thakare dan P. H. Bhagat, "Arduino-Based Smart Irrigation Using Sensors and ESP8266 WiFi Module," in Proceedings of the 2nd International Conference on Intelligent Computing and Control Systems, ICICCS 2018, 2019, doi: 10.1109/ICCONS.2018.8663041.

[7] A. A. M. Eltaieb dan Z. J. Min, “Automatic Water Level Control System," Int. J. Sci. Res., 2015. doi: 10.1016/ijss.20151505-1509.

[8] R. Sahtyawan dan A. I. Wicaksono, “Application for Control of Distance Lights Using Microcontroller Nodemcu Esp 8266 Based on Internet of Things (IoT),” Compiler, vol. 9, no. 1, Mei 2020, doi: 10.28989/compiler.v9i1.627.

[9] R. Sahtyawan, "PENERAPAN ZERO ENTRY HACKING DIDALAM SECURITY MISCONFIGURATION PADA VAPT (VULNERABILITY ASSESSMENT AND PENETRATION TESTING),” J. Inf. Syst. Manag., vol. 1, no. 1, hal. 18-22, Jul 2019. doi:10.14720/jism.2019.18-22.

[10]. S. A. Z. Murad, A. Harun, S. N. Mohyar, R. Sapawi, dan S. Y. Ten, "Design of aquaponics water monitoring system using Arduino microcontroller," in AIP Conference Proceedings, 2017, doi: 10.1063/1.5002442.

[11] V. Petrov et al., "Vehicle-Based Relay Assistance for Opportunistic Crowdsensing over Narrowband IoT (NB-IoT)," IEEE Internet ThingsJ,2018, doi:10.1109/JIOT.2017.2670363.

[12] Helmi g, Y. Somantri, Erik H“ Rancang Bangun Magnetic Door Lock Menggunakan Keypad dan 
Solenoid Berbasis Mikrokontroler Arduino Uno,” ELECTRANS, 2013.

[13] M. A. Gómez Maureira, D. Oldenhof, dan L. Teernstra, "ThingSpeak - an API and Web Service for the Internet of Things," World Wide Web, 2014.

[14] M. N. Al Hasan, C. I. Partha, dan Y. Divayana, "rancang bangun pemandu tuna netra menggunakan sensor ultrasonik berbasis mikrokontroler," Maj. Ilm. Teknol. Elektro, 2017, doi: 10.24843/mite.2017.v16i03p05. 